\title{
Comparison Analysis of LDR, NPL, ROA, CAR, and OER Before and During the Covid-19 Pandemic Period
}

\author{
Sri Ayuni ${ }^{1}$, Bornok Situmorang ${ }^{2, *}$ \\ ${ }^{1}$ Accounting Study Program, Universal University, Batam, Indonesia \\ ${ }^{2}$ Accounting Study Program, Universal University, Batam, Indonesia \\ *Corresponding author. Email: bornoksitumorang@uvers.ac.id
}

\begin{abstract}
This study aims to analyze the effect of the Covid-19 pandemics on the financial performance ratios of BPR Dana Nusantara Batam, the BPR with the best performance in the Riau Islands Province. In addition, this study uses Bank Indonesia Circular Letter No. 6/23/DPNP Year 2004 to categorize the achievement from the financial performing activities of the BPR. This research uses the case study method, followed by the analytical tool used on the SPSS Version 24, parametric statistics in the different T-tests, and nonparametric statistics through the Wilcoxon test. The results showed a significant difference in the performance of BPR Dana Nusantara in the context of achieving LDR and CAR before and during the pandemic. In contrast, the achievement of NPL, ROA, and OER did not experience significant differences. The LDR rises from the Good category to the Very Good category while NPL remains in a Good. Moreover, ROA remains in the Very Good, CAR remains in the Adequate, and OER remains in the Very Good criteria. As such, the financial performance ratios are in healthy condition, which concludes that the covid-19 pandemic did not bring a significant impact on the BPR Dana Nusantara Batam's operational activities.
\end{abstract}

Keywords: CAR, LDR, NPL, OER, ROA.

\section{INTRODUCTION}

Since the beginning of 2020, the world has experienced drastic changes, where the interactions among humans in various aspects of life are limited to social distancing and physical distancing. It happened with the outbreak of the Covid-19 virus in Wuhan, the Republic of China, on December 31, 2019 [1].

This virus was detected in Indonesia, which President Joko Widodo announced on March 3, 2020 [2]. Since then, activities and interaction patterns in Indonesia have begun to be limited by following the health protocol recommendations. The government responded by implementing a policy called LargeScale Social Restrictions [3].

Of course, these restrictions affect economic activity in almost all sectors. According to a release from the supervisory agency for financial services activities, which in this case is the Financial Services
Authority (OJK), that the profit of commercial banks in the first semester of 2020 was Rp. 62.57 trillion, which decreased as compared to the same period in 2019, which was Rp. 51 trillion where this decrease was $20.3 \%$. While net interest income from banking decreased by $2 \%$ to Rp 187.88 trillion, interest income decreased by $3.2 \%$ to Rp398.68 trillion, and the interest expense decreased by $4.3 \%$ to $\mathrm{Rp} 211.79$ trillion. Other data is that banking deposits (Third Party Funds) recorded a higher growth of $7.9 \%$. The ratio of credit to deposits or Loan to Deposit Ratio also decreased from $94.84 \%$ to $81.9 \%$. Meanwhile, the net interest margin fell from $4.9 \%$ to $4.46 \%$. [4].

Meanwhile, according to the Deposit Insurance Corporation, many BPRs have been affected by Covid-19, which leads to worries for bankruptcy [5]. The financial services authority also noted that the realization of credit restructuring throughout August 
2020 for the BPR and BPRS industries was Rp. 16.83 trillion, which involved 1,163 conventional BPRs.

In 2019, the number of BPRs in the Riau Islands and registered and published financial reports at the OJK was 27. Riau Islands Province has known as the province with the highest NPL level in Indonesia, which is $5.7 \%$. [6] and this will get worse along with the pandemic period since March 2020, which means almost the whole year 2020. The number of credit relaxations in the Riau Islands province, resulting from the pandemic until October 2020, is 106,120 debtors with a total nominal of Rp. 15.52 trillion, which is part of the relaxation given to customers of Rural Banks as well. It was disclosed directly by the OJK of the Riau Islands Province [7].

BPR Dana Nusantara is the largest BPR in the Riau Islands province in terms of asset value, as shown in Table 1:

Table 1. List of BPRs with Assets above 1 Trillion Rupiahs in 2018

\begin{tabular}{|c|c|c|c|c|c|}
\hline & List of BPRs & $\begin{array}{c}\text { Asset } \\
\text { Total } \\
\text { (Million } \\
\text { Rupiah) }\end{array}$ & $\begin{array}{c}\text { Asset } \\
\text { Increase } \\
(\%)\end{array}$ & $\begin{array}{c}\text { Tier } 1 \\
\text { Capital } \\
\text { (Million } \\
\text { Rupiah) }\end{array}$ & $\begin{array}{c}\text { Tier 1 } \\
\text { Capital } \\
\text { Increase } \\
(\%)\end{array}$ \\
\hline 1 & $\begin{array}{c}\text { BPR Eka } \\
\text { Bumi Artha } \\
\text { (PT) Kota } \\
\text { Metro }\end{array}$ & 7.728 .486 & 9,93 & 842.1 & 14,28 \\
\hline 2 & $\begin{array}{l}\text { BPR Sri Artha } \\
\text { Lestari (PT) } \\
\text { Kota Denpasar }\end{array}$ & 4.469 .349 & 9,95 & 459.28 & 19,69 \\
\hline 3 & $\begin{array}{c}\text { Bank BPR } \\
\text { Jatim Kota } \\
\text { Surabaya }\end{array}$ & 2.377 .385 & 8,28 & 487.02 & 3,26 \\
\hline 4 & $\begin{array}{c}\text { BPR Palu } \\
\text { Lokadana } \\
\text { Utama (PT) } \\
\text { Kota Palu }\end{array}$ & 2.355 .007 & 19,44 & 213.87 & 59,05 \\
\hline 5 & $\begin{array}{c}\text { BPR Hasan } \\
\text { Mitra (PT) } \\
\text { Kota Makasar }\end{array}$ & 1.987 .080 & 20,99 & 177.77 & $-1,13$ \\
\hline 6 & $\begin{array}{l}\text { BPR Surya } \\
\text { Yudhakencana } \\
\text { (PT) } \\
\text { Banjarnegara }\end{array}$ & 1.855 .969 & 23,65 & 274.74 & 20,57 \\
\hline 7 & $\begin{array}{l}\text { BPR Modern } \\
\text { Express(PT) } \\
\text { Kota Ambon }\end{array}$ & 1.777 .483 & 21,38 & 171.92 & 27,56 \\
\hline 8 & $\begin{array}{c}\text { BPR Utomo } \\
\text { Manunggal } \\
\text { Sejahtera } \\
\text { Manunggal }\end{array}$ & 1.279 .590 & 13,21 & 348.35 & 4,40 \\
\hline 9 & $\begin{array}{l}\text { BPR Dana } \\
\text { Nusantara } \\
\text { (PT) Kota } \\
\text { Batam }\end{array}$ & 1.217 .662 & 28,82 & 114,043 & 28,51 \\
\hline 10 & $\begin{array}{c}\text { BPR Irian } \\
\text { Sentosa (PT) } \\
\text { Kota Jayapura }\end{array}$ & 1.196 .356 & 32,09 & 110.87 & 24,89 \\
\hline
\end{tabular}

The purpose of this research is to analyze the comparison of the financial performance of LDR, NPL, ROA, CAR, and BOPO at PT BPR Dana Nusantara before and during the covid-19 pandemic. PT BPR Dana Nusantara Batam is known as the first and largest Rural Bank in Batam city. It provides banking services such as Savings, Deposits, and Credit in the Riau island provinces. In connection with the covid-19 pandemic, BPR Dana Nusantara also provides restructuring facilities for affected customers, whether they are individuals or entities.

Social and physical restrictions have affected economic and corporate activities. The Covid-19 pandemic has impacted BPR consumers, thus requiring credit restructuring, which will affect the BPR's performance indicators. There are concerns that BPRs will not be able to continue their operations due to the covid-19 pandemic. Thus, a comparison of the financial ratios before and during the covid-19 pandemic shall carry out.

The analysis shall benefit the company as input and additional information related to the influence and comparison of the financial performance of BPR before and during the covid-19 pandemic. For academics, the results of this study shall benefit from being a source or reference material that can help add insight and knowledge about the impact of the Covid19 pandemic on the financial performance of rural banks. Hopefully, it can be a reference material for further researchers as additional information in conducting further research, especially regarding the effect of the covid-19 pandemic on the financial performance of BPRs and comparisons between BPR's financial performance before and during the covid-19 pandemic.

\section{LITERATURE REVIEW}

\subsection{Definition of Object and Variables}

\subsubsection{Rural Bank}

Rural Bank is a bank financial institution devotes to helping the lower middle class and rural communities. According to Law number 7 of 1992 concerning Banking which has been revised by Law No. 10. of 1998, BPR is a bank that carries out business activities conventionally or based on Sharia principles (BPRS) which in its activities does not provide services in payment traffic [8].

\subsubsection{Loan to Deposit Ratio (LDR)}

Loan to Deposit Ratio (LDR) is a ratio to measure the amount of credit given compared to the number of public funds and own capital used (Kasmir, 2014). This ratio measures the extent of the capability of the bank to meet short-term obligations (liquidity) by 
dividing the total amount of credit by the total Third Party Funds or TPF (Dendawijaya, 2017) in research [1].

Formulated:

$$
\mathrm{LDR}=\frac{\text { Credit given by Bank }}{\text { Funds received by Bank }} \times 100 \%
$$

\subsubsection{Non-Performing Loan (NPL)}

A Non-Performing Loan (NPL) is a comparison between loans disbursed to the community as a whole. The NPL ratio or non-performing loan ratio is a ratio that shows the ability of bank management to manage non-performing loans provided by banks. The higher the NPL, the worse the quality of bank credit, which causes the number of non-performing loans to increase so that a bank is in a higher problematic condition [2]. Based on the BI Regulation Codification from research [2], Non-Performing Loan (NPL) is a ratio that measures the ratio of the number of nonperforming loans to total loans where:

a) Credit is credit given to third parties (not including credit to other banks)

b) Non-performing loans are loans with substandard, doubtful, and lastly, of bad qualities.

c) Non-performing loans are calculated based on a gross basis

d) Figures calculated as per position (not annualized) indicator

According to Kasmir, NPL is a comparison between all non-performing loans and the total number of loans.

Formulated:

$$
\mathrm{NPL}=\frac{\text { Sum of NPL }}{\text { Sum of given credit }} \times 100 \%
$$

\subsubsection{Return on Asset (ROA)}

Furthermore, Return on Assets (ROA) indicates the profitability of a bank based on the comparison of the level of profit after tax and the total amount of its assets. It shows the ability of the invested capital in overall assets to generate profits, which describes the bank's productivity as concerned with a brief understanding of how much wealth must be collected and used in the generation of a certain amount of profit [3].
Formulated:

$$
\text { ROA }=\frac{\text { Net Profit }}{\text { Total Asset }} \times 100 \%
$$

In this formula, several factors determine the level of profitability [4]:

a. The liquidity ratio measures the ability of the company to meet its short-term obligations calculates by comparing current assets of the company with its current liabilities;

b. The asset management ratio measures the effectiveness of the company in managing its assets; and

c. The debt management ratio determines the extent of the sufficiency of the company in financing all company activities to meet the long-term obligations.

\subsubsection{Capital Adequacy Ratio (CAR)}

The Capital Adequacy Ratio (CAR) reflects the possible risk of loss for the bank. Pandia (2012) of the research [5] defines CAR as a capital adequacy ratio for banks, which shows its capability of the bank, both in maintaining capital adequacy and bank management to identify, measure, monitor, and control emerging risks that affect the amount of capital. This ratio calculates the bank's capital divided by risk-weighted assets.

Formulated:

$$
\mathrm{CAR}=\frac{\text { Total Equity }}{\mathrm{ATMR}} \times 100 \%
$$

The CAR ratio shows the bank's ability to provide funds for business development purposes and accommodate the possible risk of loss caused in bank operations under research [6]. According to [7], The ratio is obliged to meet the minimum capital to maintain bank liquidity and measuring the bank's capital adequacy in absorbing losses and complying with the CAR (Minimum Capital Adequacy Requirement).

\subsubsection{Operational Efficiency Ratio (OER)}

OER (Operational Efficiency Ratio) is a comparison between operating costs and operating income. This ratio measures the level of efficiency and ability of the bank in carrying out its operational activities. The OER ratio is a ratio that shows the comparison between operating costs and operating income of a bank in a certain period. Operational costs generally consist of interest costs (interest expenses 
paid by the bank to customers who keep their money in the bank in the form of third-party funds), administrative costs, labor costs, marketing costs, etc. Meanwhile, bank operating income generally consists of the interest income (obtained from credit installment payments from the public), commissions, and so forth (Sofyan, 2019).

Formulated:

$$
\mathrm{OER}=\frac{\text { Operational Expense }}{\text { Operational Income }} \times 100 \%
$$

\subsection{Previous research}

Some previous research is:

a. Credit performance on the profitability of BPR during the Covid-19 pandemic. This study concludes that BPR credit performance during the pandemic increased by $1.28 \%$. There was an increase in non-current loans from $19.62 \%$ to $23.36 \%$. There was an increase in NPL from $7.95 \%$ to $8.29 \%$, and ROA decreased by $16.02 \%$.

b. The impact of the Covid 19 pandemics on the NPL of the BPRs in Indonesia. This study shows that when the incidence of the covid-19 pandemic increases by $1 \%$, the ratio will increase by $132 \%$. A Covid-19 pandemic is an extraordinary event that has caused the economy throughout the world, including Indonesia, to experience a sharp decline. The business sector experienced a deterioration in income and profits, reduced employment opportunities because many industries or companies chose to close their businesses to avoid further losses.

Comparative analysis of financial performance private and local government- owned BPR in Province of Central Java 2014-2016 period. It shows a significant difference in the financial ratios of NPL and KAP between local government-owned BPRs and privately owned BPRs. Meanwhile, there is no significant difference between CAR, LDR, OER, and ROA.

\subsection{Research Conceptual Framework}

The conceptual framework of this study is presented in Figure 1, as follows:

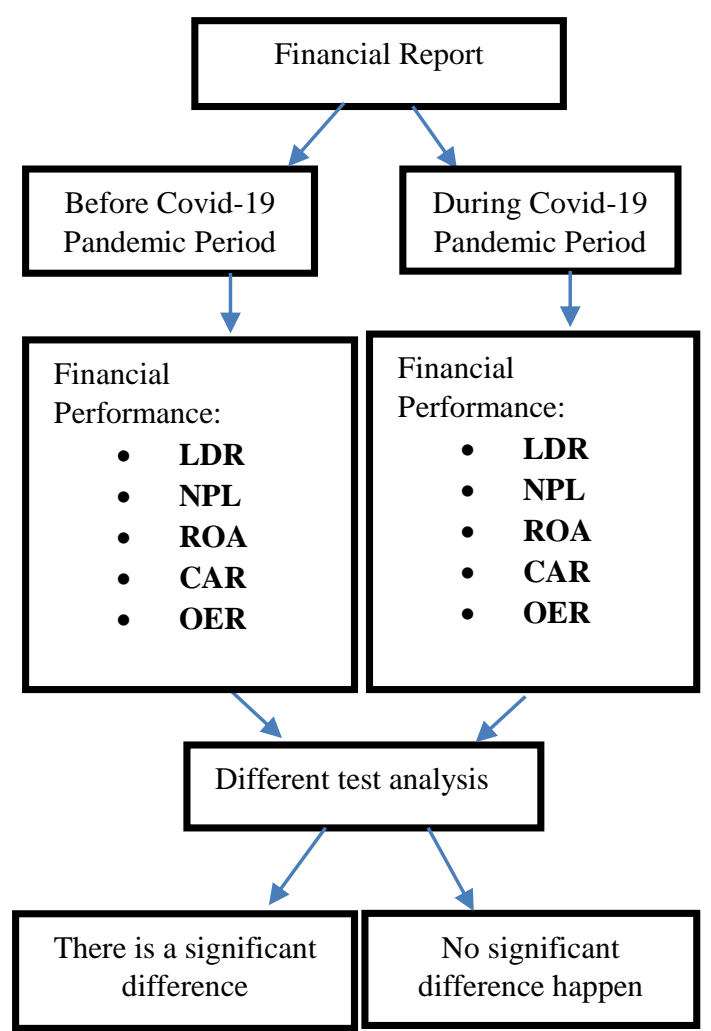

Figure 1. Research Conceptual Framework

\section{RESEARCH METHOD}

The research method takes on a quantitative approach. The investigation proceeds on the impact of the Covid-19 pandemic on Rural Bank performance based on testing a theory consisting of variables such as LDR, NPL, ROA, CAR, and OER as measured by numbers and analyzed by statistical procedures to prove the hypothesis.

The object of this research is PT BPR Dana Nusantara that operates in the Riau Islands Province. The focus of this research takes on the secondary data from BPR Financial Reports before the Covid-19 pandemic and during the outbreak of the Covid-19 pandemic with the cut-off limit during the pandemic is in March 2020, namely when the government official announcement of that Indonesia is entering a pandemic period with all the consequences that follow (government policy). 
Before analyzing the secondary quantitative data, the researchers conducted a Differential Test to examine whether the covid-19 pandemic affected the financial performance of PT BPR Dana Nusantara Batam. The test itself continues by using the Paired Sample T-Test and the Wilcoxon test because the two data variables (before and during) have a relationship with each other, namely the same data on the financial performance of PT BPR Dana Nusantara but in different periods.

The data collection method used in this research is to use primary data in the form of documentation. This method is a data collection method by taking data from published financial reports for the period June 2019 to March 2021 on the PT BPR Dana Nusantara Batam website, namely https://www.bprdn.com/index.php.
- T-Test (paired sample test) > Paired Samples Statistics, so the covid-19 pandemic has no impact on the financial performance of PT BPR Dana Nusantara

- T-Test (paired sample test) < Paired Samples Statistics, the covid-19 pandemic has an impact on the financial performance of PT BPR Dana Nusantara

However, for the non-normally distributed data, the test shall proceed with nonparametric statistics, the Wilcoxon test with the basis for making decisions: if the Asymp. Sig (2-tailed) value is less than 0.05, then $\mathrm{Ha}$ is accepted. On the opposite, the Ha shall decline if the Asymp. Sig (2-tailed) value is higher than 0.05. Table 2 below is a table of criteria used as a standard to explain the performance achievements of PT BPR Dana Nusantara.

Table 2. Categorize the BPR's performance

\begin{tabular}{|c|c|c|c|c|c|c|c|c|c|c|c|c|c|c|}
\hline \multicolumn{3}{|c|}{ Criteria of LDR } & \multicolumn{3}{|c|}{ Criteria of NPL } & \multicolumn{3}{|c|}{ Criteria of ROA } & \multicolumn{3}{|c|}{ Criteria of CAR } & \multicolumn{3}{|c|}{ Criteria of OER } \\
\hline Category & Grade & Predicate & Category & Grade & Predicate & Category & Grade & $\begin{array}{l}\text { Predi- } \\
\text { cate }\end{array}$ & Category & Grade & $\begin{array}{l}\text { Predi- } \\
\text { cate }\end{array}$ & Category & Grade & $\begin{array}{l}\text { Predi- } \\
\text { cate }\end{array}$ \\
\hline $\mathrm{LDR} \leq 75 \%$ & 1 & $\begin{array}{l}\text { Very } \\
\text { Good }\end{array}$ & $\begin{array}{l}\text { NPL }< \\
2 \%\end{array}$ & 1 & $\begin{array}{l}\text { Very } \\
\text { Good }\end{array}$ & $\begin{array}{l}\text { ROA> } \\
1,5 \%\end{array}$ & 1 & $\begin{array}{l}\text { Very } \\
\text { Good }\end{array}$ & $\begin{array}{l}\mathrm{CAR} \geq \\
12 \%\end{array}$ & 1 & $\begin{array}{l}\text { Very } \\
\text { Adeq } \\
\text { uate }\end{array}$ & $\begin{array}{l}\text { OER } \leq \\
94 \%\end{array}$ & 1 & $\begin{array}{l}\text { Very } \\
\text { Good }\end{array}$ \\
\hline $\begin{array}{l}75 \%<\text { LDR } \\
\leq 85 \%\end{array}$ & 2 & Good & $\begin{array}{l}2 \%< \\
\text { NPL } \leq \\
5 \%\end{array}$ & 2 & Good & $\begin{array}{l}1,25 \%< \\
\text { ROA } \leq \\
1,5 \%\end{array}$ & 2 & Good & $\begin{array}{l}9 \% \leq \\
\text { CAR }< \\
12 \%\end{array}$ & 2 & $\begin{array}{l}\text { Adeq } \\
\text { uate }\end{array}$ & $\begin{array}{l}94 \%< \\
\text { OER } \leq \\
95 \%\end{array}$ & 2 & Good \\
\hline $\begin{array}{l}85 \%<\mathrm{LDR} \\
\leq 100 \%\end{array}$ & 3 & Fair & $\begin{array}{l}5 \%< \\
\text { NPL } \leq \\
8 \%\end{array}$ & 3 & Fair & $\begin{array}{l}0,5 \%< \\
\text { ROA } \leq \\
1,25 \%\end{array}$ & 3 & Fair & $\begin{array}{l}8 \% \leq \\
\text { CAR< } \\
9 \%\end{array}$ & 3 & Fair & $\begin{array}{l}95 \%< \\
\text { OER } \leq \\
96 \%\end{array}$ & 3 & Fair \\
\hline $\begin{array}{l}100 \%< \\
\text { LDR } \leq \\
120 \%\end{array}$ & 4 & Deficient & $\begin{array}{l}8 \%< \\
\text { NPL } \leq \\
12 \%\end{array}$ & 4 & Deficient & $\begin{array}{l}0 \%< \\
\text { ROA } \leq \\
0,5 \%\end{array}$ & 4 & $\begin{array}{l}\text { Less } \\
\text { than } \\
\text { Fair }\end{array}$ & $\begin{array}{l}6 \%< \\
\text { CAR < } \\
8 \%\end{array}$ & 4 & $\begin{array}{l}\text { Less } \\
\text { than } \\
\text { Fair }\end{array}$ & $\begin{array}{l}96 \%< \\
\text { OER } \leq \\
97 \%\end{array}$ & 4 & $\begin{array}{l}\begin{array}{l}\text { Less } \\
\text { than } \\
\text { Fair }\end{array} \\
\end{array}$ \\
\hline & & & & & & $\begin{array}{l}\text { ROA } \leq \\
0 \%\end{array}$ & 5 & $\begin{array}{l}\text { Not } \\
\text { Fair } \\
\end{array}$ & $\begin{array}{l}\text { CAR } \leq \\
6 \%\end{array}$ & 5 & $\begin{array}{l}\text { Not } \\
\text { Fair }\end{array}$ & $\begin{array}{l}\text { OER > } \\
97 \% \\
\end{array}$ & 5 & $\begin{array}{l}\text { Not } \\
\text { Fair } \\
\end{array}$ \\
\hline
\end{tabular}

The data analysis technique is an activity to analyze research conducted by examining all data from research instruments, including notes, documents, test results, recordings, and others. It proceeds with the purpose of a more comprehensive data reading and a conclusion. Before the inferential statistical analysis, the available data shall test for their normality. Normality test proceeds through using the Shapiro-Wilk test, where if: If the value of Sig. < Research Alpha (0.05), then the data is not normally distributed, and if the value of Sig. > Alpha Research $(0.05)$, then the normality is confirmed.

Furthermore, in this study, data analysis techniques are carried out by examining the impact of the covid19 pandemic on the financial performance of PT BPR Dana Nusantara Batam. It proceeds by using a different T-Test (paired sample test). This test shall be enacted for the normally distributed data, with parametric statistics by comparing the Paired Samples Statistics value with the Sig value. (2-tailed). So the result is if:

\section{RESULT AND DISCUSSION}

\subsection{Description of Research Variables}

Before the pandemics occurred, the LDR variable had a minimum value of 75.89 and a maximum value of 81.13 . The average (mean) value is 78.3200 , and the standard deviation is 2.15348. During the pandemic, the LDR variable has a minimum value of 69.2850 and a maximum value of 75.97. The result has shown an average value (mean) of 69.2850 and a standard deviation of 5.00967. Before the Covid-19 pandemic, the NPL variable had a minimum value of 3.18 , following the maximum value of 5.49, an average value (mean) of 4.3300, and a standard deviation value of 1.07620. Likewise, during the outbreak, the minimum value is 3.01, the maximum value is 6.17 . the NPL variable has an average value (mean) of 4.5200 and a standard deviation of 1.56015. More explanation on the previous period, the ROA variable had a minimum value of 3.20 and a maximum value of 3.49 with an average (mean) of 3.3250 and a standard deviation of 0.14341 . When the pandemic occurs, the 
ROA variable has a minimum value of 3.08 and a maximum of 3.49. The average (mean) of the ratio is 3.2175 , followed by a standard deviation of 0.09394 . From the results shown, before the pandemic, the CAR variable had a minimum value of 18.17 , the maximum value of 31.62 , an average (mean) of 24.9400 , and a standard deviation of 6.93368. Likewise, during the pandemic, the CAR variable has a minimum value of 30.49 , a maximum of 36.70 , an average (mean) of 33.0600 , and a standard deviation of 2.74033. Lastly, before the pandemic, the OER variable had a minimum value of 77.68, a maximum value of 78.54 , an average (mean) of 77.9450, and a standard deviation of 0.39979 . When the pandemic occurs, the OER variable has a minimum value of 74.59 , a maximum of 77.30, an average (mean) of 75.8775, and a standard deviation of 1.38208 . The detailed description of the research variable can be seen in Table 3.

Table 3. The Description of Research Variables

\begin{tabular}{|l|c|c|c|c|c|c|c|}
\hline & $\mathrm{N}$ & Range & Min. & Max. & \multicolumn{2}{|c|}{ Mean } & $\begin{array}{c}\text { Std. } \\
\text { Dev. }\end{array}$ \\
\cline { 2 - 8 } & Stat. & Stat. & Stat. & Stat. & Stat. & $\begin{array}{c}\text { Std. } \\
\text { Error }\end{array}$ & Stat. \\
\hline $\begin{array}{l}\text { LDR_ } \\
\text { before }\end{array}$ & 4 & 5.24 & 75.89 & 81.13 & 78.3200 & 1.07674 & 2.15348 \\
\hline $\begin{array}{l}\text { LDR_ } \\
\text { during }\end{array}$ & 4 & 10.77 & 65.20 & 75.97 & 69.2850 & 2.50484 & 5.00967 \\
\hline $\begin{array}{l}\text { NPL_ } \\
\text { before }\end{array}$ & 4 & 2.31 & 3.18 & 5.4 & 4.3300 & .53810 & 1.07620 \\
\hline $\begin{array}{l}\text { NPL_ } \\
\text { during }\end{array}$ & 4 & 3.16 & 3.01 & 6.17 & 4.5200 & .78007 & 1.56015 \\
\hline $\begin{array}{l}\text { ROA_ } \\
\text { before }\end{array}$ & 4 & .29 & 3.20 & 3.49 & 3.3250 & .07171 & .14341 \\
\hline $\begin{array}{l}\text { ROA_ } \\
\text { during }\end{array}$ & 4 & .21 & 3.08 & 3.29 & 3.2175 & .04697 & .09394 \\
\hline $\begin{array}{l}\text { CAR_- } \\
\text { before }\end{array}$ & 4 & 13.45 & 18.17 & 31.62 & 24.9400 & 3.46684 & 6.93368 \\
\hline $\begin{array}{l}\text { CAR_- } \\
\text { during }\end{array}$ & 4 & 6.21 & 30.49 & 36.70 & 33.0600 & 1.37016 & 2.74033 \\
\hline $\begin{array}{l}\text { OER_- } \\
\text { before }\end{array}$ & 4 & .86 & 77.68 & 78.54 & 77.9450 & .19990 & .39979 \\
\hline $\begin{array}{l}\text { OER_- } \\
\text { during }\end{array}$ & 4 & 2.71 & 74.59 & 77.30 & 75.8775 & .69104 & 1.38208 \\
\hline $\begin{array}{l}\text { Valid N } \\
\text { (listwise) }\end{array}$ & 4 & & & & & & \\
\hline
\end{tabular}

\subsection{Inferential Statistical Analysis}

\subsubsection{Paired Sample Test}

The LDR variables before and during the pandemic have the Sig values of 0.757 and 0.363 . The variables indicate the normally distributed data due to the values being greater than 0.05. Subsequently, the NPL variables show the normally distributed data from before and during the pandemic. The Sig values of the variables, being greater than 0.05 , are 0.602 and
0.318. Likewise, the ROA variables before and during the pandemic have shown the normally distributed data. The result shows the Sig values of the variables as 0.275 and 0.151 , both of which being greater than 0.05. The CAR variables before and during the pandemic also have the normally distributed data with the Sig value. greater than 0.05 , namely 0.179 and 0.672. Lastly, the OER variable before the pandemic has non-normally distributed data, with a Sig value of 0.035 . In contrast, the OER during the pandemic has normally distributed data with a value of Sig. of 0.206 , as shown in Table 4.

Table 4. Paired Sample Test

\begin{tabular}{|l|r|r|r|}
\hline \multirow{2}{*}{} & \multicolumn{3}{|c|}{ Shapiro-Wilk } \\
\cline { 2 - 4 } & \multicolumn{1}{|c|}{ Statistic } & \multicolumn{1}{c|}{ df } & \multicolumn{1}{c|}{ Sig. } \\
\hline LDR_before & .956 & 4 & .757 \\
\hline LDR_during & .886 & 4 & .363 \\
\hline NPL_before & .931 & 4 & .602 \\
\hline NPL_during & .875 & 4 & .318 \\
\hline ROA_before & .864 & 4 & .275 \\
\hline ROA_during & .823 & 4 & .151 \\
\hline CAR_before & .834 & 4 & .179 \\
\hline CAR_during & .943 & 4 & .672 \\
\hline OER_before & .745 & 4 & .035 \\
\hline OER_during & .843 & 4 & .206 \\
\hline
\end{tabular}

\subsubsection{Normality Test of Data}

From the result of the normality test shown in Table 5, the value of Sig. (2-tailed) which is 0.10 , is being less than 0.05 . It implies a significant difference in the LDR value before and during the pandemic. On the contrary, the comparison of two variables of NPL on the table resulted in the value of Sig. (2-tailed), which is 0.877 . It indicates the Covid-19 pandemic for not affecting the NPL of the BPR due to the value of the significant level being higher than 0.05 in the criteria.

Table 5. Normality Test of Data

\begin{tabular}{|c|l|c|c|c|}
\hline \multicolumn{2}{|l|}{} & $\mathrm{t}$ & $\mathrm{df}$ & $\begin{array}{c}\text { Sig. } \\
\text { (2-tailed) }\end{array}$ \\
\hline Pair 1 & $\begin{array}{l}\text { LDR_Before_Pandemic - } \\
\text { LDR_During_Pandemic }\end{array}$ & 5.762 & 3 & .010 \\
\hline Pair 2 & $\begin{array}{l}\text { NPL_Before_Pandemic - } \\
\text { NPL_During_Pandemic }\end{array}$ & -.168 & 3 & .877 \\
\hline Pair 3 & $\begin{array}{l}\text { ROA_Before_Pandemic - } \\
\text { ROA_During_Pandemic }\end{array}$ & 2.017 & 3 & .137 \\
\hline Pair 4 & $\begin{array}{l}\text { CAR_Before_Pandemic - } \\
\text { CAR_During_Pandemic }\end{array}$ & -3.257 & 3 & .047 \\
\hline
\end{tabular}


Similarly, the value Sig. (2-tailed) of 0.137, which is greater than 0.05 , signifies the pandemic for having no impact on the ROA of the BPR. Likewise, the Covid-19 pandemic affects the CAR of the BPR where the value Sig. (2-tailed) of 0.047 , which is smaller than 0.05 , indicates a significant difference in CAR before and during the pandemic.

Due to the data on the OER variable is nonnormally distributed, the inferential statistical test shall proceed through the use of the Wilcoxon test.

Table 6. Wilcoxon Test

\begin{tabular}{|l|r|}
\hline & \multicolumn{2}{|c|}{$\begin{array}{l}\text { OER_during_Pandemi - } \\
\text { OER_before_Pandemi }\end{array}$} \\
\hline$Z$ & $-1.826^{\mathrm{b}}$ \\
\hline Asymp. Sig. (2-tailed) & .068 \\
\hline
\end{tabular}

Based on the results shown in Table 6 , the value of Asymp. Sig. (2-tailed) of 0.068 is being higher than 0.05 in the level of significance. It signifies that the pandemic does not affect the OER of the BPR.

\subsection{Discussion}

The significant value being 0.010 on the LDR proves the effect of the pandemic on the financial ratio. Further proof is from the average LDR before the pandemic, which was $78.32 \%$ fell to the Good category. When the pandemic occurs, the average LDR falls to $69.285 \%$, which considers being the Very Good category. For further explanation, the NPL, with a significance value of 0.877 , indicates no significant difference. The average percentage of the NPL before the pandemic was $4.33 \%$ in the Good criteria, while during the pandemic was $4.52 \%$, classified into the Good category. Similarly, the Return on Assets ratio before and during the pandemic experienced an insignificant comparison, with a significant value of 0.137 . The average ROA value before the pandemic was $3.325 \%$ which was in the Very Good criteria. Likewise, there is a drop of the average percentage to $3.2175 \%$, but still in the Very Good category. The Capital Adequacy Ratio before and during the pandemic showed an increase. Based on the difference test, this increase was significant, indicated by a significance value of 0.047 . The average CAR value before the pandemic was $24.94 \%$ in the Adequate category. When the pandemic occurs, the average percentage of the CAR is higher by $8.12 \%$, despite being in the Adequate criteria. On the contrary, the condition of the Operational Efficiency Ratio shows a decline. This decrease is insignificant, evidenced by a significant value from the different tests based on the
Wilcoxon test of 0.068 (> 0.05). The average OER value before the pandemic was $77.945 \%$ which fell under the Very Good category. During the Covid-19 pandemics, the percentage is decreased to $75.8775 \%$ and classified to be Very Good.

\section{CONCLUSION}

Based on the results of research and discussion, it can be concluded in this study as follows:

1. There is a significant difference in the performance of BPR Dana Nusantara in the context of achieving the Loan to Deposit Ratio before and during the pandemic, where the average achievement has decreased from the Good category to the Very Good category.

2. There is no significant difference in the performance of BPR Dana Nusantara in the context of achieving Non-Performing Loans before and during the pandemic. The achievement of the average NPL figure has increased and remains in a Good category.

3. There is no significant difference in the performance of BPR Dana Nusantara in the context of achieving Return on Assets before and during the pandemic. The achievement of the average ROA has decreased but is still in the Very Good category.

4. There is a significant difference in the performance achievement of BPR Dana Nusantara in the context of the Capital Adequacy Ratio before and during the pandemic, where the CAR achievement has increased and remains in the Adequate category.

5. There is no significant difference in the performance of BPR Dana Nusantara in the context of achieving Operational Expenses on Operating Income before and during the pandemic. The achievement of the average BOPO value has decreased and is getting stronger on the Very Good criteria.

\subsection{Suggestion}

In an effort for further development, the authors will convey several suggestions, namely: for future researchers, the authors hope that this research can be developed by adding more relevant information, adding research objects, and research scope. 


\subsection{Research Contributions}

This research becomes a provision in the understanding of the financial performance of bank management. Hopefully, this research shall be a resourceful help to make policy preferences and actions to deal with the pandemic.

From the company's perspective, this research shall use as input and additional information related to the influence and comparison of the BPR's financial performance before and during the pandemic.

\section{ACKNOWLEDGMENTS}

The authors thank the parties involved in this study, mainly the PT BPR Dana Nusantara, with the data provided and the Universal University for a conducive atmosphere in conducting research.

\section{REFERENCES}

[1] A. Afriyeni and J. Fernos, "Analisis FaktorFaktor Penentu Kinerja Profitabilitas Bank Perkreditan Rakyat (Bpr) Konvensional di Sumatera Barat," J. Benefita., vol. 3, no. 3, pp. 325-335, 2018, doi: 10.22216/jbe.v3i3.3623.

[2] M. I. H. Tiwu, "Pengaruh Pandemic Covid 19 Terhadap NPL Bank Perkreditan Rakyat di Indonesia," Akunt. Transparansi dan Akuntabilitas., vol. 8, no. 2, pp. 79-87, 2020.

[3] U. Harun, "Pengaruh Ratio-Ratio Keuangan CAR, LDR, NIM, BOPO, NPL Terhadap ROA," Ris. Bisnis dan Manajemen., vol. 4, no. 1, pp. 67-82, 2016.

[4] M. Sofyan, "Faktor-Faktor Yang Mempengaruhi Profitabilitas Bank Perkreditan Rakyat (BPR) di Provinsi Jawa Timur," Inspirasi Bisnis dan Manajemen., vol. 3, no. 1, pp. 63-76, 2019, doi: 10.33603/jibm.v3i1.2093.

[5] R. Anggriani and P. Muniarty, "The Effect of Non-Performing Loans ( NPL ) and Capital Adequacy Ratio ( CAR ) on Profitability (ROA) at PT . Bank Central Asia (BCA), Tbk," Ilomata Int. J. Management., vol. 1, no. 3, pp. 121-126, 2020.

[6] A. Widya Prananta, Yulianti, and Anita Damajanti, "Analisis Komparasi Kinerja Keuangan BPR milik Swasta dan BPR milik Pemerintah Daerah di Provinsi Jawa Tengah Periode 2014-2016," Akunt. Indonesia., vol. 8, no. 1, pp. 57-73, 2019.
[7] D. Mainata and A. F. Ardiani, "Pengaruh Capital Adequacy Ratio (CAR) Terhadap Return On Aset (ROA) Pada Bank Syariah," Al-Tijary, vol. 3, no. 1, p. 19, 2018, doi: 10.21093/at.v3i1.960.

[8] M. Sofyan, "Pengaruh CAR, NPL, BOPO dan ROA Terhadap LDR (Studi pada BPR di Kabupaten Provinsi Jawa Barat Pada Semester I 2016)," J. Ilm. Ekbank., vol. 2, no. 1, pp. 5064, 2019. 